\title{
Doğu Karadeniz Dağlarında Erken Demir Çağı Varlığına İlişkin Yeni Buluntular
}

\section{The Most Recent Findings Related to the Early Iron Age at the Eastern Black Sea Mountains}

\author{
Hülya Çalışkan Akgül1
}

1Sorumlu yazar/Corresponding author: Hülya Çalışkan Akgül, (Dr. Öğr. Üyesi), Karadeniz Teknik Üniversitesi, Edebiyat Fakültesi, Arkeoloji Bölümü, Trabzon, Türkiye E-posta: kalinka301@hotmail.com ORCID ID: 0000-0002-6619-9898

Başvuru/Submitted: 30.10 .2020 Kabul/Accepted: 03.12 .2020

Atıf/Citation: Caliskan Akgul, H. (2020). Doğu Karadeniz dağlarında erken demir çağı varlığına ilişkin yeni buluntular. Anadolu AraştırmalarıAnatolian Research, 23, 91-111.

https://doi.org/10.26650/anar.2020.23.818496

\section{Öz}

Trabzon'un arkeolojik geçmişi daha çok antik dönem yazılı kaynaklardaki veriler dikkate alınarak açıklanmaya çalışılmaktadır. Ancak bu geçmiş arkeolojik yönden kanıtlanamamaktadır. Bölge az sayıda ve sürekliliği olmayan yüzey araştırmalarına sahne olmuştur. 2018 yılında başlatılan Trabzon Ili Protohistorik Dönem Yüzey Araştırmaları Projesi ile bölgenin bilinmeyen geçmişi aydınlatılmaya çalışılmaktadır. Araştırmanın 2019 yılı sezonunda incelenen alanlarından biri, Maçka ilçe sınırları içindeki Mulaga Vadisi'dir. Vadide, Zırvanos mezrasının güneyinde, yaklaşık 2000 m yükseklikteki Kalecik (Mile) Kalesi'nde, Erken Demir Çağı́nın tanımlanmasını mümkün kılan seramik parçalar tespit edilmiştir. Saptanan seramikler hamur özellikleri, yüzey işlemleri, form ve bezeme özellikleri bakımından Van Gölü Havzası́nın kuzeyi, kuzeydoğu Anadolu ve Transkafkasya Erken Demir Çağ seramik repertuarı ile benzerlik göstermektedir. Doğu Karadeniz Dağları́nın kuzeye bakan yamaçlarında yer alan Kalecik (Mile) Kalesi ile birlikte bölgede ilk defa Erken Demir Çağı hakkında değerlendirme yapabileceğimiz arkeolojik materyal ele geçmiş ve Doğu Anadolu Erken Demir Çağı için Doğu Karadeniz Dağları́nın bir bariyer oluşturmadığı anlaşılmıştır.

Anahtar Kelimeler: Doğu Karadeniz, Trabzon, Erken Demir çağı, Kale türü yerleşim, Seramik

\section{ABSTRACT}

Archaeological past of Trabzon has been explained by considering the data in the written sources of antique era -to date. However, so-far this history cannot be proved archaeologically. The region has witnessed a few, short-term surveys, which did not continue long. Trabzon Protohistoric Period Survey Project which was started in 2018 aims to increase data about the region. In 2019 survey season, Mulaga Valley in Maçka was one of the areas where reseach was conducted. In this valley, south to Zirvanos at Kalecik (Mile) Castle with an altitude of 2000 m, ceramic pieces dated to the Early Iron Age were identified.. These ceramic findings show similarities with the Early Iron Age ceramic repertoire of the northern part of the Van Lake basin, northeastern Anatolia, and Transcaucasia with regard to their paste, surface treatment, and decoration. Kalecik (Mile) Castle findings allows for the first time to interpret Early Iron Age in the region. This paper argues that Eastern Black Sea Mountains were actually not a barrier for the Eastern Anatolian Early Iron Age.

Keywords: Eastern Black Sea, Trabzon, Early Iron age, Castle settlement, Ceramic 


\section{EXTENDED ABSTRACT}

Amongst Anatolian archaeology, Trabzon is a scene of few and discontinued surveys. The history of the region can be traced only as early as to the middle of first millennium $\mathrm{BC}$ through written sources of the antique era yet not proved with archaeological data. The textual records document that before and after the Helen colonization (i.e., beginning of the second quarter of first millennium BC), the region has not been desolated but inhabited by local communities. Trabzon Protohistoric Period Survey started in 2018 aims to display the region's pre-Classic Ages.

The Survey area in Trabzon was divided into two major plans as littoral and inner regions. Valleys of the streams splitting the territory through the north-south direction allow the inner regions to access the Black Sea and sub-regional mountain ridges.. Maçka, which became the main focus of the survey, is an important gate that connects Black Sea littoral to inner districts. To understand the pre-Classic Age of this geo-strategically important area, survey has been planned considering a route north to south. Accordingly, Maçka can be divided into five sub-regions form west to east; Mulaga, Değirmendere (this valley, which starts from Trabzon, is also called Hamsiköy Valley on south to Maçka), Larhan, Altındere/Meryemana and Atasu/Galyan. In 2019 survey season, the Mulaga Valley, which is located as the farthest to the south Maçka, was investigated.

To the south of Zırvanos/Üçgedik District in Mulaga Valley, a rocky field just to the north-west of the Kalecik district is located. Being at the altitude of $2000 \mathrm{~m}$, the inhabitants call the area Kalecik (Mile) Castle. This rocky field lies east to west and is $130-30 \mathrm{~m}$ in size. The entrance of the castle, which seems to be built on a rocky surface, could not be detected. However the natural conditions as a plain field suggest a possible entrance at the north-west points. A plastered wall with $4.5 \mathrm{~m}$ width and $6 \mathrm{~m}$ height ascends solely on the rocky field towards the north to the castle. Our team has been informed that some parts of the fortification wall has been exploded by some raiders using dynamites. In the middle of this rocky field, a circular and filled well with a diameter of $2 \mathrm{~m}$ is located. A second well is also detected to $2 \mathrm{~m}$ east of the first, however the field is heavily destructed to allow further interpretation. Near the northern slope of the castle several scattered ceramic pieces were found. However, any architectural finding associated to the finds cannot be detected. A through studied on the ceramics demonstrate a sequence from the Early Iron Age to the Middle Age.

Majority of the ceramic pieces are dated to Early Iron Age. Their surface are mostly brown. One of the pieces with mineral tempering has incised decoration. Outer surfaces of some pieces are black, bright burnished and smooth while inner surfaces are mottled black. This dark pattern on outer surface is most likely related with firing technique and mottling seems to be a result of secondary firing process. Moreover, both surfaces of the piece show of tournette marks. 
Ceramic findings demonstrate similar features with the ones found in the north of the Van Lake Basin (Patnos, Çaldıran, Ernis/Evditepe) and in the north-eastern Anatolian (Bozkurt Kurgan-Cemetary 1, Büyükardıç) Early Iron Age ceramic repertoire regarding the paste, surface treatment, production technique, typology, and decoration. These ceramic pieces prove that the cultural characteristics of the Eastern Anatolian Early Iron Age could also be followed in the Eastern Black Sea mountains. This assertation is for the first time in Trabzon region, for a site at a considerable altitude and castle-type.

Geography of the area around the Kalecik castle evokes at the plains of the Eastern Anatolia in contrart to the dense forested characteristic of Black Sea region. When the altitude is over $1000 \mathrm{~m}$, it becomes less humidity as well as sub-humid and semi-arid plains become available. The region must have been suitable for transhumance during the Early Iron Age, as it is practiced today. In this context, the area of Kalecik Castle could be proposed as a region with environmental features that people with castle-like settlements of Early Iron Age were "used to".

Trabzon is also important with its ore resources. Especially Maçka region has rich reserves of pyrite, copper, iron, lead, zinc, molybdenum, and manganese. Although prehistoric usage of these resources have not been confirmed yet, this potential is almost impossible to go unnoticed by the Iron Age communities. This communities must have processed iron along with copper and introduced products with increasing experience on metallurgical activities. Compared to the different regions of Anatolia, one of the greatest challenges in archaeological studies in Trabzon is literally the "lack" of surface visibility. This difficulty makes existence of ceramic pieces especially importance. The findings detected at Kalecik castle in 2019, for the first time, make an archaeological interpretation about Early Iron Age in Trabzon possible. 


\section{Giriş}

Trabzon, Anadolu arkeolojisi içinde az sayıda ve sürekliliği olmayan yüzey araştırmalarına sahne olmuş bir bölgedir. Buna bağlı olarak bölgenin geçmişi de en erken MÖ 1. Binyıl ortalarına kadar gitmektedir. Daha çok antik dönem yazılı kaynaklara dayanan bu geçmişin arkeolojik buluntularla kanıtlanamaması sorunu bilimsel güvenilirliğe de gölge düşürmektedir. Örneğin, kentin MÖ 756 y1lında Hellenli kolonistler tarafindan kurulduğu (Carpenter, 1948, s. 1-10; Drews, 1976, s. 18-31) ve bölgedeki kentsel yaşamın da onlarla birlikte başladığı şeklindeki hem antik hem de çağdaş kaynaklarda geçen bilginin arkeolojik buluntular açısından bir geçerliliği yoktur. Ancak söz konusu metinlerde, MÖ 1. binin ikinci çeyreğinden itibaren bölgede başlayan Hellen kolonizasyonu öncesinde ve sonrasında bölgenin boş olmadığı ve bazı yerel topluluklar tarafından iskân edildiği de belirtilmektedir (Ksen. Anab. V.4.1; Tsetskhladze, 2007; Demirel, 2019, s. 130).

2018 yılında başlatılan Trabzon İli Protohistorik Dönem Yüzey Araştırması Projesi (TYAP) ile bölgenin Klasik Çağlar öncesine ait bilgi eksikliğinin giderilmesi amaçlanmaktadır. Bölgeye komşu Orta Karadeniz, Doğu Anadolu ve Güney Kafkasya'daki tarihöncesi döneme ait arkeolojik bulgular nispeten iyi belgelenmiştir (Alkım, Alkım ve Bilgi 1988, 2003; Sagona, 2017). Trabzon bölgesinden elde edilmeye başlanan veriler ile sözü edilen coğrafyalar arasındaki kronolojik ve kültürel bağlantıların daha iyi tanımlanacağı düşünülmektedir. Bu makalede, 2019 yılı arazi çalışmalarında tespit edilen ve şimdiye kadar bölgede ilk defa tanımlanan Erken Demir Çağı seramik buluntular tanımlanmakta ve Trabzon'un söz konusu dönem içindeki yeri ve önemi tartışılmaktadır.

\section{8-2019 Yılları TYAP Araştırma Alanı ve Çalışma Yöntemi}

Yüzey araştırması kapsamında çalışma alanı, bölgenin coğrafi ve jeolojik özelliklerine göre sahil kesimi ve iç bölgeler olmak üzere iki ana bölüme ayrılmıştır. İç bölgelerin Karadeniz'e ulaşması bakımından bölgeyi kuzey-güney doğrultusunda yaran akarsu vadileri ile bunların arasındaki sırtlar alt bölgeleri oluşturmaktadır. 2018-19 yıllarında gerçekleştirilen yüzey araştırmasının çalışma sahaları Trabzon-Merkez, Maçka ve Düzköy ilçelerini içermektedir (Çalışkan Akgül, Kılıç ve Demirel 2019; Çalışkan Akgül, Kılıç, Demirel ve Yılmaz 2020). Erken Demir Çağı'na atfedilen seramik buluntular, Trabzon'un en büyük ilçesi olan Maçka'da tespit edilmiştir.

Günümüzde iç kesimler ile sahil arasındaki iletişim derin vadiler boyunca uzanan ve dağların alçaldığı ana güzergahlar üzerinden sağlanmaktadır. Trabzon ilinin batısında su bölümü çizgisi, Değirmendere Havzası'nın güneyi boyunca dağları alçalan bir şekilde aşarak Zigana Dağları'nda bir omuz oluşturur. Böylece burası 2000 m. yüksekliği ile Karadeniz kıyılarını iç bölgelere bağlayan önemli bir jeo-stratejik geçit olan Trabzon-İran transit karayoluna zemin oluşturur. Trabzon ili sınırları bu bölümden itibaren dağ zirvelerinden 
güneye doğru girinti yapar (Erinç, 1945; Emir, 2008). Dolayısıyla Maçka, iç bölgeleri Karadeniz sahiline bağlayan önemli bir geçit yeridir. Maçka, doğudan batıya doğru sıralanan vadilerle 5 alt bölgeye ayrılmaktadır. Bunlar doğudan batıya doğru sırası ile Atasu/Galyan, Altındere/Meryemana, Larhan, Değirmendere (Trabzon'dan başlayan vadiye Maçka'nın güneyinde Hamsiköy Vadisi denilmektedir) ve Mulaga Vadileri'dir (Resim 1). Jeo-stratejik öneme sahip bu bölgenin Klasik Çağlar öncesindeki konumunu anlayabilmek, vadilerin güzergahları doğrultusunda planlanan bir araştırma hattı ile mümkündür. 2018-19 araştırma sezonlarında söz konusu vadiler ve vadiler arasındaki sırtlar, ayrı birimler olarak ele alınmış ve incelenmiştir. Yüzey araştırmamız sırasında, geç dönemlere tarihlendirilen yerleşim türlerinin daha erken dönemlerden itibaren kullanılma olasılığı dikkate alınmaktadır. Nitekim yazıya konu edilen Kalecik (Mile) Kalesi'nde ${ }^{1}$, söz konusu çalışma yöntemini destekler nitelikte seramik buluntular tespit edilmiştir.

İlk iki yıl sonucunda elde edilen bulgular 1şı̆̆ında, sahil kesimini oluşturan Trabzon/ Merkez ilçe, Helenistik, Roma, Doğu Roma ve Osmanlı dönemleri bakımından zengin buluntu alanlarını ortaya koymaktadır. Maçka ilçesinde, özellikle Değirmendere vadisi (güneyde Hamsiköy vadisi olarak isimlendirilir) boyunca ve vadiye hâkim konumlarda, Geç Roma ve Doğu Roma İmparatorluğu'na tarihlendirilen kaleler bulunmaktadır. Ayrıca Maçka ilçesinde üç ayrı alanda cüruf kalıntıları tespit edilmiştir. Trabzon/Merkez ve Maçka ilçelerinde çok sayıda mağara ve kaya sığınağı tespit edilmesine rağmen insan faaliyetlerine ilişkin taş aletler saptanamamıştır. Neolitik Çağ öncesine atfedilen çakmaktaşı ve obsidiyen buluntular ise şimdilik Düzköy ilçesinde tespit edilmiştir (Çalışkan Akgül vd., 2020).

Arkeolojik çalışmaların az sayıda olmasına bağlı olarak yetersiz veriye sahip olan bölgenin değişmeye başlayan durumunun yeni çalışmalarla daha da netleşeceği öngörülmektedir (Çalışkan Akgül 2016). Maçka’nın güneyinde yükselen Doğu Karadeniz Dağları zirvelerinin arkasında (Gümüşhane ve Bayburt illerinde) Kalkolitik, Tunç ve Demir Çağları kültürlerine ait bulgular kayda geçirilmiştir (Sagona ve Sagona, 2004; Çiğdem, 2008). Trabzon'da yürütülen yüzey araştırmasıyla prehistorik kültürlerin Doğu Karadeniz Dağları'nı kuzey yönde aşıp aşmadıkları, araştırmanın amaçları arasında yer almaktadır.

\section{Erken Demir Çağı Buluntu Alanları}

\section{Kalecik (Mile) Kalesi}

Mulaga Vadisi'ndeki Üçgedik mahallesine bağlı Zırvanos mezrasının güneyinde, yaklaşık 2000 m yükseklikte yer alan Kalecik mezrasının hemen kuzeybatısındaki kayalık

1 Kalecik Kalesi, yüzey araştırmamızın ardından, tespit edilen harçlı mimari kalıntılar ve çoğunluğu oluşturan Doğu Roma Dönemi seramik parçaları göz önünde bulundurularak, Trabzon Kültür Varlıklarını Koruma Bölge Kurulu Müdürlüğü tarafından “Korunması Gerekli 1'inci Grup Taşınmaz Kültür Varlığı” olarak tescillenmiştir (Karar Tarihi ve No: 20.10.2020 - 6012). 
alan yerel halk tarafından Kalecik (Mile) Kalesi olarak adlandırılmaktadır (Resim 1). Doğubatı doğrultusunda uzanan kayalık alan yaklaşık olarak 130 x 30 m boyutlarındadır. Kayalık alan üzerine inşa edildiği anlaşılan kalenin girişi tespit edilememiştir. Ancak doğal şartlar kalenin tek düz alanı olan kuzeybatıdan bir girişi mümkün kılmaktadır.

Kalenin yalnızca batıdaki kayalık alanında, $4.5 \mathrm{~m}$ geniş̧liğinde ve $6 \mathrm{~m}$ yüksekliğinde, harçlı bir duvar kalıntısı bulunmaktadır (Resim 2). Surun bazı kısımlarının da yakın zamanda defineciler tarafından dinamitle patlatıldığı bilgisi mezrada yaşayanlardan öğrenilmiştir. Kayalık alanın ortasında yaklaşık $2 \mathrm{~m}$ çapında, içi doldurulmuş dairesel bir kuyu bulunmaktadır. Kuyunun hemen 2 m doğusunda ikinci bir kuyu daha saptanmış, ancak alanın fazla tahrip olması nedeniyle tam olarak işlevi anlaşılamamıştır.

Doğudaki kayalık alanda ise mimariye dair bir iz tespit edilememiştir. Kalenin kuzey yamacında, kaleden aşağıya döküldüğü anlaşılan çok sayıda çanak çömlek parçası saptanmış ancak herhangi bir mimari kalıntı tespit edilmemiştir. İncelenen çanak çömlek parçaları Erken Demir Çağı, Orta ve Geç Doğu Roma² dönemlerine tarihlenmektedir (Resim 3).

\section{Kalecik (Mile) Kalesi Erken Demir Çă̆ı Seramik Buluntuları}

Kalecik Kalesi seramik buluntuları ilk defa Doğu Karadeniz Dağları'nın kuzeyinde Erken Demir Çağı'nın tanımlanmasını mümkün kılmaktadır (Resim 4). Arazide incelenen seramik parçalarının çoğunluğu açık kahverengi yüzey tonlarına sahiptir. Mineral katkılı ve el yapımı olan buluntulardan en tanımlayıcı olanlar, çömlek parçası ve bezemeli bir gövde parçasıdır (Resim 4: 2-3). Dış yüzeyleri ince astarlı ve hafif açkılıdır. Ağız kenarı dışa kalınlaştırılmış çömlek parçası kısa boyunlu bir forma sahiptir. Kazıma bezemeli gövde parçasının üst kısmında iki yiv arasında birbirine paralel eğik kazıma hatlar, alt kısmında ise sığ oluklar şeklinde yapılmış eğik hat sırası bulunmaktadır.

Daha az sayıda parça ile temsil edilen koyu yüzlü grup içindeki, ağız kenarı içe kalınlaştırılmış çanak parçasının kesitinde hamur koyu kahve renktedir (Resim 4: 1). Ancak diş yüzeyler siyah renkte, parlak açkılı ve oldukça pürüzsüz, bazı örneklerde iç yüzeyler ise siyah tonlarında alacalıdır. Dış yüzeylerdeki koyu renk, kabın fırınlanması ile ilişkili görünürken, iç yüzeylerdeki alacalanmanın ise ikincil pişirim ile ilgili olduğu düşünülmektedir. Ayrıca parçaların her iki yüzeyinde düzensiz, ağır dönen çark izleri mevcuttur.

Söz konusu seramik buluntular, hamur, yüzey işlemleri, yapım tekniği, kap formu ve bezeme özellikleri bakımından Van Gölü’nün kuzeyindeki Ernis-Evditepe Nekropolü, Patnos ve Çaldıran bölgeleri ile kuzeydoğu Anadolu'daki Bozkurt Nekropolü (Mezarlık 1)

2 Geç dönem seramik repertuarını inceleyen Dr. G. Kan Şahin söz konusu parçaları Orta ve Geç Doğu Roma dönemlerine tarihlendirmektedir. Resim 3'te yer alan seramik parçalar sırsız sade tabak, testi, pişirme kapları ve Zeuksippus tekniğinde kazıma dekorlu bir sırlı kâseden oluşmaktadır. 
ve Büyükardıç Erken Demir Çağ seramik buluntuları ile benzerlik göstermektedir. Trabzon bölgesinde ilk defa, oldukça yüksek bir rakımda, kale türü bir yerleşmede saptadığımız bu türdeki seramik buluntular MÖ 2. binyıl sonunda başlayan Doğu Anadolu Erken Demir Çağı kültür özelliklerinin Doğu Karadeniz Dağları'nda da takip edilebileceğinin ilk ipuçlarıdır. Saptanan Erken Demir Çağı seramiklerinin, daha kuzeyde, sahil kesimine yakın alanlardaki yayılım durumu şimdilik net değildir. Bu noktada Maçka ilçe merkezinin kuzeydoğusundaki Konakdüzü Mevkii önemli görülmektedir.

\section{Konakdüzü Mevkii}

Maçka'nın kuzeydoğusunda, ormanlık alan içinde, Konakdüzü adı verilen kayalık sırtın batı eteklerinde, yuvarlak planlı bir taş yığını saptanmıştır (Resim 5). Buluntu alanı şekli nedeniyle, bölge halkı tarafından, "Kurgan" olarak isimlendirilmektedir. Altındere/ Meryemana Vadisi ile Atasu/Galyan Vadisi arasında yer alan bu sırt, kuzeyde Esiroğlu'ndan itibaren yükselmeye başlamakta ve güneyde İskobel yaylasına doğru devam etmektedir (Resim 1).

Alanda kuzey-güney doğrultulu harçsız duvar kalıntıları bulunmuştur ${ }^{3}$. Defineci çukurları nedeniyle etrafa saçılmış taşların genelde işlenmemiş olduğu görülmektedir. Ancak yüzeydeki dağınık taşlar arasında, kısa kenar yüzünde dört adet oyuk bulunan dikdörtgen formda işlenmiş bir blok taş da vardır (Resim 6). Seramik parçaları ise etrafa saçılmış taşların arasında tespit edilmiştir. Çoğunlukla küçük amorf parçalardan oluşan seramik buluntular nem nedeniyle oldukça kırılgandır. Koyu kızıl-kahve renkte hamurlu parçaların yüzeyleri aşınmış olduğu için astar ve açkı gibi yüzey işlemlerine dair izler ya da çark izleri gözlenmemektedir (Resim 7). Sadece bir parçanın üzerinde çark izi olduğu anlaşılmaktadır. Yoğun mineral katkılı parçalardan bir tanesi çanak, bir diğeri ise çömleğe ait ağız parçasıdır. Kalın-dörtgen kesitli ağızlı, küresel gövdeli derin çanağın hemen ağız kenarının altında, iki sıralı yatay sokma-nokta bezeme yer alır (Resim 8: 1-2). Çömlek ise dışa açılan ağız kenarlı ve k1sa boyunludur (Resim 8: 3).

\section{Trabzon Bölgesindeki Tarihlendirme Sorunu}

Trabzon, kronolojik sıradüzen içinde tanımlanmış arkeolojik materyal eksikliği nedeniyle arkeolojik araştırmalar için oldukça zorlayıcıdır. Bu sebeple, saptanan herhangi

3 Karadeniz Teknik Üniversitesi Jeofizik Mühendisliği öğretim üyeleri Prof. Dr. Aysel Şeren ve Dr. Ali Erden Babacan tarafindan, söz konusu alanda, 250 ve $500 \mathrm{MHz}$ korumalı antenlerle yer radarı test ölçümleri gerçekleştirilmiş̧ir. Alandaki yüzey koşullarına bağlı olarak farklı yönlerde beş hatta ilgili ölçüler toplanmıştır. Yüzeyde görülen ancak tahrip olmuş duvar kalıntılarının yanı sıra test ölçümlerinde yüzeyin $0.2-0.7 \mathrm{~m}$ derinlikleri arasında, biri kuzey-güney diğeri ise doğu-batı doğrultusunda görülen yansımalar dikkat çekmektedir. Yapılan incelemelerde alanın bir kurgan olmadığı anlaşılmıştır. Test ölçülerinde farklı doğrultularda yansımaların tespit edilmesi üzerine gelecek araştırma dönemlerinde Konakdüzü Mevkii yer radarı çalışmasının daha detaylı bir biçimde tekrar edilmesi planlanmaktadır. 
bir buluntunun göreli tarihlendirmesi dahî kolay değildir. Bu sorunla baş edebilmek için yüzey araştırmasında uygulanan yöntem, öncelikle bölgenin coğrafi konumuna odaklanmak ve Trabzon'da saptanması beklenen arkeolojik dönemleri gerekçeleri ile birlikte ortaya koymaktır. Buluntuların makroskopik analizi, tipolojik özellikleri ve benzerlerini saptamak çalışmaların başlangıcı için önemlidir.

Araştırma alanı, Karadeniz Havzası'nın güneydoğu kesiminde yer alır ki bu konum onu Kafkasya ile Anadolu dünyası arasına yerleştirmektedir. Ancak, Arkeoloji literatüründe "kültürler arası iletişim ve etkileşim” bağlamında, Doğu Anadolu-Kafkasya (Sagona, 2000), Doğu Anadolu-Mezopotamya (Frangipane, 2015), Kafkasya-Mezopotamya (MaxwellHyslop, 1971; Abramishvili, 2010) ve Kuzey Pontus-Anadolu (Tsetskhladze, 1999) eksenindeki çalışmalarda Türkiye'nin Doğu Karadeniz bölgesi haklı olarak ya tartışma dışında bırakılmış ya da sayılan bölgeler bağlamında genel hatları ile ele alınmıştır. Bu durum sadece Erken Demir Çağı için değil, tüm çağlar için geçerlidir.

Araştırma alanından saptanan materyalin kronolojik bir sıradüzen içinde değerlendirilebilmesi için uygulanan bir başka yöntem de bölgede bilinen en geç dönemden başlayarak geriye doğru gitmektir. Özellikle sahil bölgesi, çeşitli nedenlerden dolayı tahrip olmakla birlikte, baskın geç dönem (Roma, Doğu Roma, Ortaçağ) özellikleri gösteren buluntu alanları ve arkeolojik materyale sahiptir (Emir, 2008, s. 21-22). Bu yazının konusunu oluşturan seramik parçaları hem teknolojik hem de tipolojik yönden sahil bölgesi geç dönem seramik buluntularından farklıdır. Bu nedenle Klasik Çağ'a kıyasla çok daha erken bir evrenin ele alınması gerekmektedir.

Coğrafi konum ve bölgede bilinen geç dönem seramik parçalarından farklı oluşunun ardından, Erken Demir Çağı olarak tanımlanan bu seramiklerin tespit edildiği alandaki yerleşim türünün özelliği ele alınmaktadır. Söz konusu seramik parçaları kale olarak tanımlanan bir alandan gelmektedir. Kale türü yerleşimler hem Güney Kafkasya'da hem de Doğu Anadolu'nun doğusunda, Erken Transkafkasya Kültürü'nün ardından, bir diğer ifade ile, MÖ 2. Binyıldan itibaren görülmektedir (Kushnareva, 1997, s. 84-149; Özfirat, 2001, 2006). Seramikler, hamur özellikleri, yüzey işlemleri, form ve bezeme özellikleri bakımından, Kuzeydoğu Anadolu ve Van Gölü Havzası'nın kuzeyindeki Erken Demir Çağı seramik repertuarı ile benzerlik gösterir ki, söz konusu dönem yine kale türü yerleşimler ve nekropoller ile karakterize olmaktadır (Belli ve Konyar 2003; Özfirat, 2014).

\section{Seramik Buluntuların Tarihlendirilmesi ve Karşılaştırmalı Analizi}

Doğu Anadolu'da Demir Çağı'nın başlangıcı ile bu dönemde teknolojik, sosyal ve kültürel değişimleri başlatanların kim olduğu konuları arkeolojideki güçlü tartışmalardandır (Özdemir, 2007, s. 507-508). Bu bağlamda Doğu Anadolu için güçlü Urartu Krallığı, Erken Demir Çağı'nın tanımlanmasında da baskın bir kültürel süreçtir (Köroğlu ve Konyar 2005, s. 
25). Sonuçta, Erken Demir Çağı tanımı ile Urartu Krallığı'nın öncesi, bir başka ifade ile Van Gölü Havzası'nda ekonomik, politik ve sosyo-kültürel birliğin daha kurulmadığı ve aşiret düzeninin hâkim olduğu bir yaşam tarzı ifade edilmektedir (Köroğlu, 2009, s. 383-385). Özellikle bölgede mezar buluntuları ile saptanan, ancak höyüklerin tabakalaşmasında tespit edilemeyen bu sürecin tanımı, Uruadri ve Nairi beyliklerinden söz eden MÖ 13. yüzyıl Assur çivi yazılı kaynakları ile de desteklenmektedir (Çilingiroğlu, 1994, s. 1, 9-15).

Söz konusu bölgede kazısı yapılan höyüklerin hepsinde İlk Tunç Çağı'na tarihlendirilen tabakaların üstünde Urartu dönemi mimari kalıntıları tespit edilmiş, Erken Demir Çağı ise alandaki çöp çukurları ve silolardan saptanan çanak çömlek buluntular ile tanımlanabilmiştir (Çilingiroğlu, 1991; Sevin, 2004, s. 362). Höyüklerdeki seramik kapların teknik ve biçim özelliklerinin nekropol alanlarındaki örneklerle benzerlik gösterdiği vurgulanmakta, böylece, daha çok buluntu karşılaştırmasına dayanan tarihlendirmenin alt yapısı kurgulanmaktadır. Ancak nekropol alanlarından gelen buluntuların yeniden incelenmesi, mezarların Erken Demir Çağı'na tarihlendirilme konusunu yeniden gündeme taşımakta; mezarlıklar ile buluntuların MÖ 9-7. yüzyıllar arasına tarihlenmesi önerilmektedir (Köroğlu ve Konyar 2005, s. 35-36).

Van Gölü Havzası'nda Erken Demir Çağı kronolojisi için Kuzeybatı İran ile güçlü paralellikler kurulmaktadır. Bu bağlamda gri renkli yeni bir seramik geleneği ile İran'a gelen kavimlerin, bölgede yeni bir kültürel süreci başlattıkları ve bu sürecin de MÖ 15 . yüzyıla kadar geri çekilebildiği ileri sürülmektedir (Young, 1965, 70; Konyar, 2004, 11). Van Gölü Havzası'nda Karagündüz'den elde edilen C14 sonuçları MÖ 1250-1120 aralığını vermektedir (Sevin, Özfirat ve Kavaklı 2001, s. 356). Ancak yukarıda açıklandığı gibi, Karagündüz nekropol buluntuların yeniden değerlendirilmesi farklı kronolojik yaklaşımları ortaya koymaktadır.

Kuzeydoğu Anadolu'nun önemli tarihöncesi dönem yerleşmelerinden biri olan Sos Höyük, Erken Demir Çağı için güçlü veriler ortaya koymamakla birlikte Son Tunç Çağı'ndan sonraki farklı kültürel özelliklerin MÖ 1200-855 yılları arasına tarihlendirilmesini sağlamıştır (Sagona, 1999, 157).

Doğu Anadolu'nun batısında, Malatya-Elazı̆̆ Bölgeleri'nde ise Erken Demir Çağı buluntuları, höyüklerde nispeten daha güçlü bir biçimde saptanmıştır. Korucutepe'den (Elazığ) alınan C14 sonucu, Erken Demir Çağı için, MÖ 1150-950 tarih aralığını vermektedir (van Loon, 1971, 55).

Yukarıda tanımlandığı gibi, Kalecik Kalesi ve Konakdüzü Mevkii seramik buluntuları, yüzey renkleri ve yüzey işlemleri bakımından üç ayrı grupta değerlendirilebilir. Sadece koyu yüzey renkli parçalarda düzensiz, ağır dönen çark izleri tespit edilmiş, diğer parçaların el yapımı olduğu anlaşılmıştır. 
Kalecik Kalesi'ndeki koyu yüzey rengine sahip seramik parçalar, mal grubu olarak daha çok Van Gölü'nün kuzeyinde ve Erzurum Bölgesi'nde saptanan koyu yüzlü malı, ya da diğer bir tanımlama ile gri-siyah açkılı malı hatırlatmaktadır (Sagona, 1999, s. 157; Işıklı ve Erdem 2009, s. 255, 260; Marro ve Özfirat 2005, s. 328). Erken Demir Çağı'nın belirleyici mal gruplarından biri olarak tanımlanan Gri-Siyah mal grubunun yayılım alanı, Güney Kafkasya, Kuzeydoğu Anadolu ve Urmiye Gölü Havzası'na konumlandırılmaktadır (Konyar, 2004, s. 339; Ayaz, 2017, s. 349-351). Malatya-Elâzı̆̆ bölgesi höyüklerinde ise koyu yüzey renkli seramik buluntular tespit edilmekle birlikte seramik repertuarının içinde oldukça az sayıdadır (Hauptmann, 1969/70, s. 58). Bu mal grubu içindeki çanak parçasının form bakımından en yakın benzeri yine Van Gölü Havzası'nın kuzeyindeki Patnos bölgesi örnekleri içinde tespit edilmektedir (Konyar, 2004, lev. CXVI: 3). Ağız kenarı dışa kalınlaştırılmış çömleğin form bakımından en yakın benzerleri ise Kuzeydoğu Anadolu bölgesinde Ağrı/Bozkurt Nekropolü (Mezarlık 1) ile Erzincan/Büyükardıç yerleşmesinde saptanmıştır (Ayaz, 2017, Lev. LXXXVIII:1-2; CIV: 5).

Kalecik Kalesi'nde saptanan diğer örnekler ise, ince astarlı, düzgün yüzeyli ve hafif açkılı olması bakımından Doğu Anadolu Erken Demir Çağı seramik repertuarı içinde baskın olan mal grupları ile benzerlik göstermektedir. Kazı bezemeli parçada yatay yivler arasındaki sağa ya da sola yatık hatlardan oluşan bezeme tarzı ise Ernis-Evditepe Nekropolü'nün yanı sıra Patnos ve Çaldıran bölgelerinden Van Müzesi'ne gelen örnekleri de hatırlatmaktadır (Konyar, 2004, lev. CIII: 2, CXVIII: 4). Aynı bezeme tarzı ayrıca Malatya-Elâzığ bölgesinin güçlü yerleşimlerinden Norşuntepe ve Korucutepe'nin Erken Demir Çağ seramik buluntuları içinde de belgelenmiştir (Konyar, 2004, lev. III: 2,6, V: 1,10).

Konakdüzü Mevkii amorf seramik buluntuların benzerlerini bulmak ya da doğrudan Doğu Anadolu Erken Demir Çağı kültürü ile ilişkilendirmek zordur. Ancak örnekler mal grubu bakımından Erken Demir Çağı'nın başında Doğu Anadolu'da ortaya çıkan Kahve-Kiremit mal grubuyla benzerlik gösterir (Ayaz, 2017, s. 346-349). Çanak formunun en yakın benzeri ise Büyükardıç örneklerinde tespit edilebilmektedir (Ayaz, 2017, Lev. XCV: 5). Bu çanak parçasındaki iki sıralı sokma-nokta bezeme tarzı ise özellikle Ernis-Evditepe Nekropolü ve Patnos ve Çaldıran bölgesi Erken Demir Çă̆ı seramik repertuarındaki bezeme örneklerine yakındır (Sevin, 1996, Resim 7; Konyar, 2004, lev. XCII: 1, CXVII: 1, CXIX: 4). Bunun yanı sıra ilginç bir biçimde Batı Kafkasya'da MÖ 2. Binyıl ile 4. Yüzyıl arasına tarihlendirilen uzun soluklu Kolkhis kültürü seramiklerinin bezeme özelliklerini de anımsatmaktadır (Vickers ve Kakhidze 2008, s.137).

Mal grubu ve form bakımından yapılan karşılaştırmalar sonucunda, Trabzon bölgesinde ilk kez saptanan ve Erken Demir Çağı'na atfedilen seramik parçalarının benzerleri için, Van Gölü Havzası'nın kuzeyinde (Patnos, Çaldıran ve Ernis/Evditepe) ve Kuzeydoğu Anadolu'daki (Büyükardıç ve Bozkurt Kurgan-Mezarlık 1) yerleşme ve nekropollerdeki 
Erken Demir Çağı seramik repertuarı ve bunun yanı sıra Batı Kafkasya'da Kolkhis kültürü seramik bezeme özellikleri ön plana çıkmaktadır.

\section{Doğu Anadolu Erken Demir Çağı'nda Doğu Karadeniz Bölgesi’nin Yeri}

Prehistorik yönden bilinmeyenleri çok olan Trabzon'un yerini sadece Erken Demir Çağı için değil, şimdiye kadar hiç tespit edilemeyen Neolitik, Kalkolitik ve Tunç Çağları bakımından da ortaya koyabilmek oldukça zordur. Bu noktada öncelikle bölgenin coğrafi yapısına değinmek gerekmektedir.

Yüzey araştırması sahası, yükseltisi 0 ile 2660 m arasında değişen, güneyden-kuzeye doğru akış gösteren birçok akarsu tarafından derin yarılmış vadiler ve sahanın güneyinde yer alan 1500-2000 m arasında uzanan platolar ile Zigana dağlık alanından oluşmaktadır (Atalay ve Mortan 1997, s. 16-17, 68). Bölgedeki vadilerin yamaçları oldukça diktir ve çoğu yerde \%100 eğimi geçmektedir. Bu da sahadaki insan faaliyetlerini zorlaştırmaktadır. Kıyıdan içeride, Düzköy (Kale) ve Mulaga vadileri arasında Oba Platosu, Mulaga ve Hamsiköy vadileri arasında ise Kale Platosu bulunmaktadır (Resim 1). Yaklaşık 1800-2000 m yükseltiye sahip bu platolar yer yer derin vadilerle parçalanmış durumdadır. Platoların güneyinde, Zigana dağlık alanı bulunmakta, araştırma sahasını güneyden bir hilal şeklinde kapatarak Doğu Anadolu'ya geçişte önemli bir set oluşturmaktadır. Burada, yükseltiye bağlı olarak bitki örtüsü de değişmektedir. Sahadaki ormanlar, yer yer 2000 m ye kadar çıkmakta, çok nadiren 2000 m yi geçmektedir. Bu seviyeden sonra sıcaklıkların azalması ve vejetasyon süresinin kısalmasına bağlı olarak, yaylacılık faaliyetlerinin yürütüldüğü alpin çayırlar başlamaktadır. Bu sahalar kış aylarında genelde karla örtülüyken, yaz mevsiminde karlar erimekte, çoğu günler sis ve bulut örtüsü ile kaplanmaktadır. Temmuz ve Ağustos aylarında güneşli gün sayısı oldukça sınırlıdır.

Kalecik Kalesi'nin bulunduğu alanın coğrafi özellikleri, sık ormanlarla kaplı Karadeniz Bölgesi'nden çok Doğu Anadolu'nun yaylaları ile benzerlik göstermektedir. İklim bakımından da bölgede $1000 \mathrm{~m}$ seviyesinden sonra nemlilik azalmakta ve yarı nemli ve kurak-yarı nemli sahalar karşımıza çıkmaktadır (Yılmaz ve Çiçek 2016). Bölgede, günümüzde zaten uygulandığı gibi, yaylacılık faaliyetleri için geçerli optimum koşullar (Zaman, 2001) Erken Demir Çağı için de geçerli olmalıdır. Bu bağlamda Kalecik Kalesi’nin yer aldığı alan, Doğu Anadolu yaylalarında kale türü yerleşimlerde saptanan Erken Demir Çağı kültürünün "alışkın olduğu” çevresel özelliklere sahiptir (Resim 9).

Trabzon maden yatakları bakımından da önemli bir bölgedir. Özellikle Maçka çevresi pirit-bakır, demir-bakır, bakır-kurşun-çinko, kurşun-çinko, kurşun, bakır, molibden ve manganez yatakları bakımından oldukça zengindir (MTA 2019). Bu madenlerin prehistorik dönemlerde çıkarılıp çıkarılmadığına dair somut bir veri şimdilik saptanabilmiş değildir. Ancak Geç Kalkolitik döneme tarihlendirilen Arslantepe VIA kerpiç sarayı içinde ele geçen 9 
kılıç ve 12 mızrak ucundan 4 tanesinin hammadde kaynağı için Doğu Karadeniz önerilmiştir (Hauptmann, Schmitt-Strecker, Begemann ve Palmieri 2002, s. 64-65). Dolayısıyla bölgenin prehistorik dönem madencilik faaliyetleri bakımından öncelikle bakır yataklarının varlığı dikkat çekicidir. Söz konusu potansiyelin, bakırın yanı sıra demiri işleyebilen ve metalürjik faaliyetlerde artan bir tecrübe ile ürünler ortaya koyan Demir Çağı halkları tarafından da fark edilme olasılığg oldukça yüksektir. Bu dönemde Doğu Karadeniz Bölgesi, zengin maden yataklarına (McConchie, 2004, s. 43) ve demir yönünden zengin siyah renkli kumsallarına (Tylecote, 1981, s. 138) ulaşabilme bakımından da elverişli bir bölge olmalıdır.

\section{Sonuç}

Anadolu'nun farklı bölgeleri ile kıyaslandığında Trabzon'un arkeolojik araştırmalardaki en büyük zorluklarından biri yüzey görünürlüğünün oldukça az olmasıdır. Böyle bir zorluk, eski dönemlere ait seramik buluntuların anlamının da büyük olmasını sağlamaktadır. 2019 yılında Kalecik Kalesi'nde saptanan seramik parçaları, Trabzon bölgesinde ilk defa arkeolojik materyal çerçevesinde Erken Demir Çağı hakkında yorum yapabilmemizi mümkün kılmıştır.

Daha çok yüzey araştırmalarına bağlı olan Doğu Karadeniz Bölgesi verilerine göre Erken Demir Çağı buluntu grubu az sayıdaki seramik malzemeye dayanmaktadır. Bölgede şimdilik sadece Artvin ve Bayburt'ta kesin bir ifade ile Erken Demir Çağı tanımının kullanıldığı seramik malzeme tespit edilmiştir (Sagona ve Sagona 2004; Alkan, 2019, s. 188). Ad1 geçen iller ile karşılaştırıldığında, Trabzon/Maçka'daki Kalecik Kalesi ve Konakdüzü Mevkii buluntuları Doğu Karadeniz Dağları'nın kuzeye bakan yamaçlarında yer alır. Kesin sonuçlardan bahsedebilmek için çalışmaların erken bir safhası olmakla birlikte, ilk verilere göre söz konusu dönem için yüksek ve sarp Doğu Karadeniz Dağları'nın bir bariyer oluşturmadığı gözlenmektedir.

Şüphesiz ki, söz konusu buluntu grubu beraberinde şu soruları gündeme getirmektedir: Konakdüzü Mevkii gerçekten antik kaynaklarda adı geçen MÖ 1. binyıl halklarıyla ilişkilendirilebilir mi? Yoksa bu halklar sahil kesimine doğru yayılmış olan Doğu Anadolu karakterli topluluklar mıdır? Bölgedeki yerel halkların kökeni MÖ 2. binyıla kadar geri çekilebilir mi? Kalecik Kalesi'ndeki gibi “Doğu Anadolu ilişkili kültürel ögelere sahip Erken Demir Çağı halkları”, Doğu Karadeniz Bölgesindeki yerel halklarla iletişim ve etkileşim içine girdiler mi?

Elbette bu aşamada, bu gibi daha birçok soru "varsayımsal” olarak tartışılabilir. Bölgenin sessizliği ise ancak arkeolojik kanıtlar ile bozulabilir. Anadolu'nun eski çağlarında "terra incognita" özelliğine sahip bu topraklardaki yeni arkeolojik buluntular, yeni tartışma alanları açmakta ve güçlü kanıtlar sunmaktadır. 
Teşekkür: TYAP 2019 yılı arazi çalışmalarına sağladıkları finansal destek nedeniyle Türk Tarih Kurumu, Trabzon Mimarlar Odası, Trabzon Ticaret ve Sanayi Odası ve Doğu Karadeniz İhracatçılar Birliği’ne araştırma ekibi adına teşekkür ederim. Araştırma sahasının coğrafi ve jeolojik özelliklerini arkeolojik buluntu alanları çerçevesinde değerlendirerek görüş ve önerilerini esirgemeyen Dr. Erkan Yılmaz'a ve özverili çalışmaları, destek ve önerileri için TYAP ekibinin her bir üyesine teşekkürü bir borç bilirim.

Hakem Değerlendirmesi: Dış bağımsız.

Çıkar Çatışması: Yazar çıkar çatışması bildirmemiştir.

Finansal Destek: Karadeniz Teknik Üniversitesi Bilimsel Araştırma Projeleri Koordinasyon Birimi tarafından desteklenmiştir (Proje No SAT-2020-8417).

Peer-review: Externally peer-reviewed.

Conflict of Interest: The author has no conflict of interest to declare.

Grant Support: This work was supported by the Scientific Research Projects Coordination Unit of Karadeniz Technical University (Project number SAT-2020-8417).

\section{Kisaltmalar}

\section{TYAP: Trabzon İli Protohistorik Dönem Yüzey Araştırması Projesi}

\section{Kaynakça/References}

Abramishvili, M. (2010). In search of the origins of metallurgy - An overview of South Caucasian evidence. S. Hansen, A. Hauptmann, I. Motzenbäcker ve E. Pernicka (Eds.), Von Majkop bis Trialeti Gewinnung und Verbreitung von Metallen und Obsidian in Kaukasien im 4.-2. Jt. v. Chr. içinde (s. 167-178). Bonn: Dr. Rudolf Habelt GmbH.

Alkan, Ö. (2019). Tarihi ve Arkeolojik Veriler Işığında Artvin. (Doktora tezi). Atatürk Üniversitesi Sosyal Bilimler Enstitüsü, Erzurum.

Alkım, U. B., Alkım, H. ve Bilgi, Ö. (1988). İkiztepe I. Birinci ve İkinci Dönem Kazıları (1974-1975). Ankara: Türk Tarih Kurumu Yayınları.

Alkım, U. B., Alkım, H. ve Bilgi, Ö. (2003). İkiztepe II. Üçüncü, Dördüncü, Beşinci, Altıncl, Yedinci Dönem Kazıları. Ankara: Türk Tarih Kurumu Yayınları.

Atalay, İ. ve Mortan, K. (1997). Türkiye Bölgesel Coğrafyası. İstanbul: İnk1lap Kitabevi.

Ayaz, G. (2017). Doğu Anadolu Bölgesi Erken Demir Çağ Çanak Çömlek Kültür Bölgeleri: Gelişimleri, Sinırları, Çanak Çömlek Grupları ve İlişkileri Çerçevesinde Değerlendirilmesi. (Doktora Tezi). Van Yüzüncü Yıl Üniversitesi Sosyal Bilimler Enstitüsü, Van.

Belli, O. ve Konyar, E. (2003). Doğu Anadolu'da Erken Demir Çağı Kale ve Nekropolleri-Early Iron Age Fortresses and Necropolies in Eastern Anatolia. İstanbul: Arkeoloji ve Sanat Yayınları.

Carpenter, R. (1948). The Greek Penetration of the Black Sea. American Journal of Archaeology, 52 (1), 1-10. Çalışkan Akgül, H. (2016). Türkiye'nin Doğu Karadeniz Bölgesi'nin Prehistoryası: Bir Terra Incognita Analizi. Karadeniz Incelemeleri Dergisi, 21, 9-26. https://doi.org/10.18220/kid.277658.

Çalışkan Akgül, H., Kılıç, S. ve Demirel, S. (2019). Trabzon İli Protohistorik Dönem (Kalkolitik ve Tunç Çağları) Yüzey Araştırması 2018 Yılı Ön Sonuçları. Araştırma Sonuçları Toplantısı, 37 (2) içinde (s. 253-276). Diyarbakır.

Çalışkan Akgül, H., Kılıç, S., Demirel, S. ve Yılmaz, E. (2019-2020). Trabzon İli Protohistorik Dönem Yüzey Araştırmas1 - 2019. Türk Eskiçă̆ Enstitüsü Haberler, 45, 67-73. 
Çiğdem, S. (2008). Gümüşhane Bölgesi'nin Tarih ve Arkeoloji Araştırmaları. Erzurum: T.C. Gümüşhane Valiliği Yayınları 6.

Çilingiroğlu, A. (1991). The Early Iron Age at Dilkaya. A. Çilingiroğlu, D.H. French (Eds.), Anatolian Iron Ages, II içinde (s. 29-38). Ankara.

Çilingiroğlu, A. (1994). Urartu Tarihi. İzmir: Ege Üniversitesi Edebiyat Fakültesi Yayınları.

Demirel, S. (2019). MÖ 1. Binyılda Doğu Karadeniz' in Yerel Toplulukları. Karadeniz Araştırmaları Enstitüsü Dergisi, 5 (8), 129-141. https://doi.org/10.31765/karen.668091.

Drews, R. (1976). The Earliest Greek Settlements on the Black Sea. The Journal of Hellenic Studies, 96, 18-31.

Emir, O. (2008). Prehistorik Dönemden Roma Dönemine Kadar Trabzon ve Çevresi. Trabzon: Serander Yayınlar1.

Erinç, S. (1945). Kuzey Anadolu Kenar Dağlarının Ordu-Giresun Kesiminde Landşaft Şeritleri. Türk Coğrafya Dergisi, 7, 119-140.

Frangipane, M. (2015). Different types of multiethnic societies and different patterns of development and change in the prehistoric Near East. Proceedings of the National Academy of Sciences of the United States of America, 112 (30), 9182-9189.

Hauptmann, H. (1969/70). Historische Geographic und Ergebnisse der Grabungen. İstanbuler Mitteilungen, 19-20, 21-78.

Hauptmann, A., Schmitt-Strecker, S., Begemann, F. \& Palmieri, A. (2002). Chemical Composition and Lead Isotopy of Metal Objects from the "Royal" Tomb and Other Related Finds at Arslantepe. Eastern Anatolia. Paléorient, 28 (2), 43-69.

Işıkl1, M. \& Erdem, A. Ü. (2009). A group of Early Iron Age pottery from the Erzurum Region. Archäologische Mitteilungen aus Iran und Turan, 41, 249-268.

Konyar, E. (2004). Doğu Anadolu Erken Demir Çağ Kültürü: Arkeolojik ve Yüzey Araştırmaları Bulgularının Değerlendirilmesi. (Doktora Tezi). İstanbul Üniversitesi Sosyal Bilimler Enstitüsü, İstanbul.

Köroğlu, K. (2009). Urartu Dönemi Bey Konakları. H. Sağlamtimur, Z. Derin, A. Ü. Erdem, A. Batmaz, F. Dedeoğlu, M. Erdalkıran, M. Bilge Baştürk, E. Konakçı. (Eds.). Altan Çilingiroğlu'na Armağan: Yukarı Denizin Kıylsında Urartu Krallığı'na Adanmış Bir Hayat içinde (s. 383-394). İstanbul: Arkeoloji ve Sanat Yayınları.

Köroğlu, K. ve Konyar, E. (2005). Van Gölü Havzası'nda Erken Demir Çağı Problemi. Arkeoloji ve Sanat, 119, 25-38.

Ksen. Anab. (1922). C. Lewis Brownson, Anabasis, The Anabasis, (1866-1948), London: Harvard University Press, Cambridge, MA.

Kushnareva, Kh.K. (1997). The Southern Caucasus in Prehistory, Stages of Cultural and Socioeconomic Development From The Eight to The Second Millennium B.C. (H.N. Michael Çev.) Philadelphia: The University Museum, University of Pennslyvania.

Marro, C. \& Özfirat, A. (2005). Pre-Classical Survey in Eastern Turkey. Third Preliminary Report: Doğubeyazıt and Eastern Shore of Lake Van. Anatolia Antiqua, XIII, 319-356.

Maxwell-Hyslop, K. R. (1971). Western Asiatic jewellery c. 3000-612 B.C. London.

Mcconchie, M. (2004). Archaeology at the North-East Anatolian Frontier, V: Iron Technology and Iron-Making Communities of the First Millenium BC. Ancient Near Eastern Studies, Supplement 13. Louvain: Peeters.

MTA Trabzon Bölge Müdürlüğü. (2019). Trabzon İli Masif Tip Cu, Pb, Zn Yatak ve Zuhurları Envanteri. Trabzon. 
Özdemir, H.F. (2007). Demir Çağı: Başlangıcı ve Başlatanları, Anadolu'ya Etkileri Üzerine. Çukurova Üniversitesi Sosyal Bilimler Enstitüsü Dergisi, 16 (1), 501-518.

Özfirat, A. (2001). Doğu Anadolu Yayla Kültürleri. İstanbul: Arkeoloji ve Sanat Yayınları.

Özfirat, A. (2006). The Middle Bronze Age Settlement Pattern of the Eastern Anatolian High Plateau in Light of New Evidence. D.L. Peterson, L.M. Popova, A.T. Smith (Eds.), Beyond the Steppe and The Sown: Proceedings of the 2002 University of Chicago Conference on Eurasian Archaeology, Colloquia Pontica 13, içinde (s. 160-171). Brill Leiden-Boston.

Özfirat, A. (2014). Bozkurt Kurgan Nekropolü Kazısı. A. Özfirat, N. Coşkun (Eds.), Mustafa Kemal Üniversitesi Fen-Edebiyat Fakültesi Arkeoloji Bölümü Kazı ve Araştırmaları içinde (s. 45-70). Antakya: Mustafa Kemal Üniversitesi Yayınları.

Sagona, A. (1999). The Bronze Age-Iron Age Transition in Northeast Anatolia: a view from Sos Höyük. A. Çilingiroğlu ve R.J. Matthes (Eds.), Anatolian Iron Ages 4, Anatolian Studies, 49, 153-157.

Sagona, A. (2000). Excavations at Sos Höyük, 1998 to 2000: Fifth Preliminary Report. Ancient Near Eastern Studies, 37, 56-127.

Sagona, A. (2017). The Archaeology of the Caucasus: From Earliest Settlements to the Iron Age. Cambridge: Cambridge University Press.

Sagona, A. \& Sagona C. (2004). Archaeology at the North-East Anatolian Frontier, I, An Historical Geography and a Field Survey of the Bayburt Province. Ancient Near Eastern Studies Supplement 14, Louvain: Peeters Press.

Sevin, V. (1996). Van/Ernis (Ünseli) Nekropolü Erken Demir Çağ Çanak Çömlekleri. Anadolu Araştırmaları XIV, Prof. Dr. Afif Erzen'e Armağan, 439-467.

Sevin, V. (2004). Son Tunç/Erken Demir Çă̆ Van Bölgesi Kronolojisi Kökeni Aranan Bir Devlet: Urartu. Belleten, LXVIII (252), 355-386.

Sevin, V., Özfirat, A. ve Kavaklı, E. (2001). 1997-1999 Hakkâri Kazıları. Kazı Sonuçları Toplantısı, 22 (I) içinde (s. 355-368). Ankara: Kültür Bakanlığı Milli Kütüphane Basımevi.

Tsetskhladze, G. R. (1999). Between west and east: Anatolian roots of local cultures of the Pontus. G.R. Tsetskhladze (Ed.), Ancient Greeks West and East içinde (s. 469-496). Leiden, Boston, Cologne. https:// doi.org/10.1163/9789004351257-020.

Tsetskhladze, G. R. (2007). Greeks and Locals in the Southern Black Sea Littoral: A Re-Examination. G. Herman ve I. Shatzman (Eds.), Greeks between East and West: Essay in Greek Literature and History in Memory of David Asheri içinde (s. 160-195). Jarusalem: The Israel Academy of Sciences and Humanities.

Tylecote, R. F. (1981). Iron Sands from the Black Sea. Anatolian Studies, 31, 137-139.

Van LOON, M. (1971). Korucutepe Kazıs1, 1969, Mimari ve Genel Buluntular. Keban Projesi 1969 Çalışmaları içinde (s. 47-56). Ankara.

Vickers, M. \& Kakhidze, A. (2008). A Kolchian and Greek Settlements: Excavations at Picvnari 1967 to 2005. P.G. Bilde ve J.H. Petersen (Eds.), Meetings of Cultures in The Black Sea Region, Between Conflict and Coexistence içinde (s. 131-148). Aarhus: Aarhus University Press.

Yılmaz, E. ve Çiçek, İ. (2016). Türkiye Thornthwaite İklim Sınıflandırması. Journal of Human Sciences, 13(3), 3973-3993.

Young, T.C.JR. (1965). A Comparative Ceramic Chronology for Western Iran, 1500-500. Iran, III, 53-84.

Zaman, M. (2001). Tonya İlçesinin Coğrafi Etüdü. Trabzon: Tonya Belediyesi Kültür Yayınları. 


\section{Figürler}

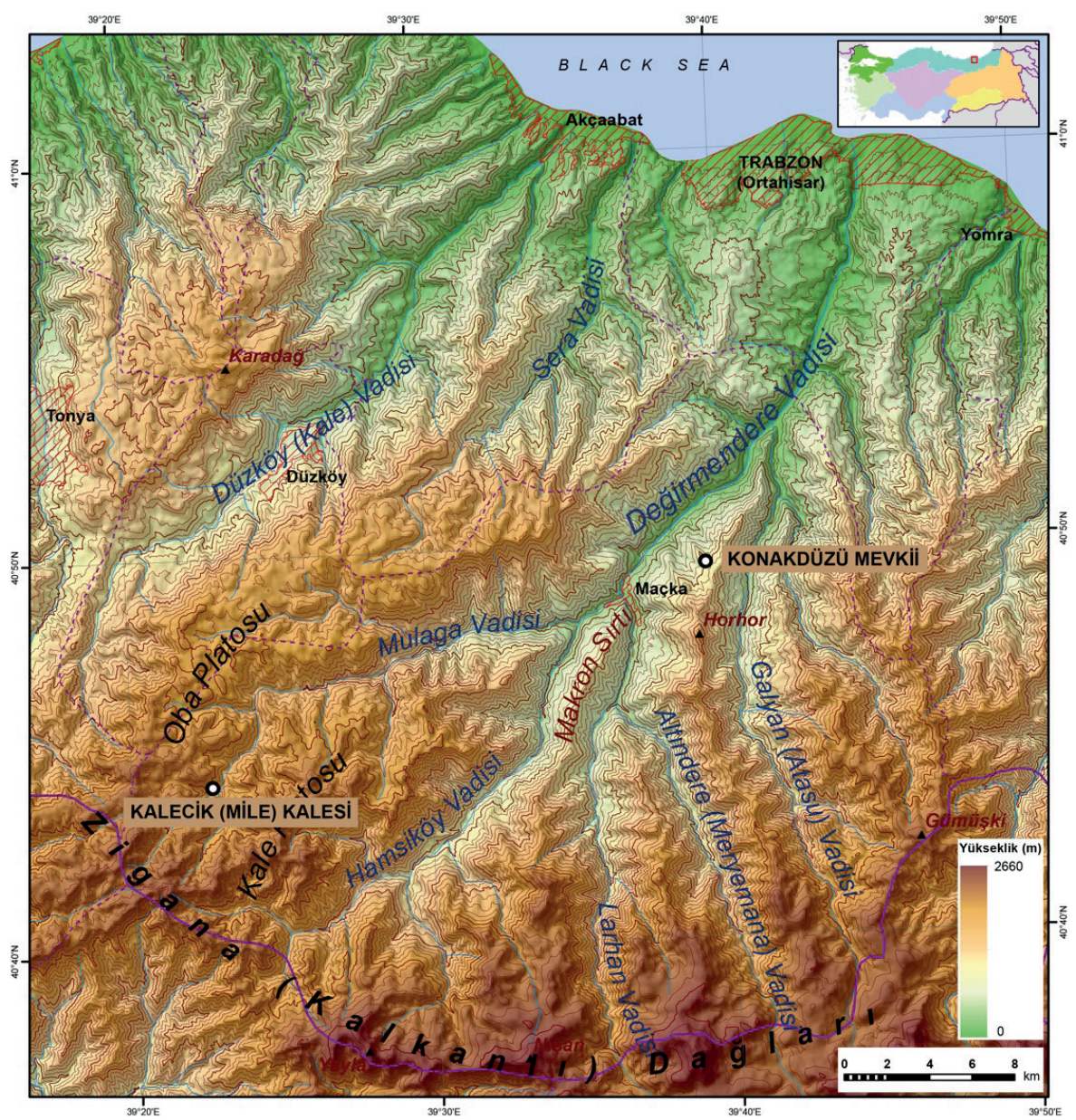

Resim 1. Metinde geçen Erken Demir Çağı buluntu alanları - Trabzon (Harita Dr. E. Y1lmaz). 


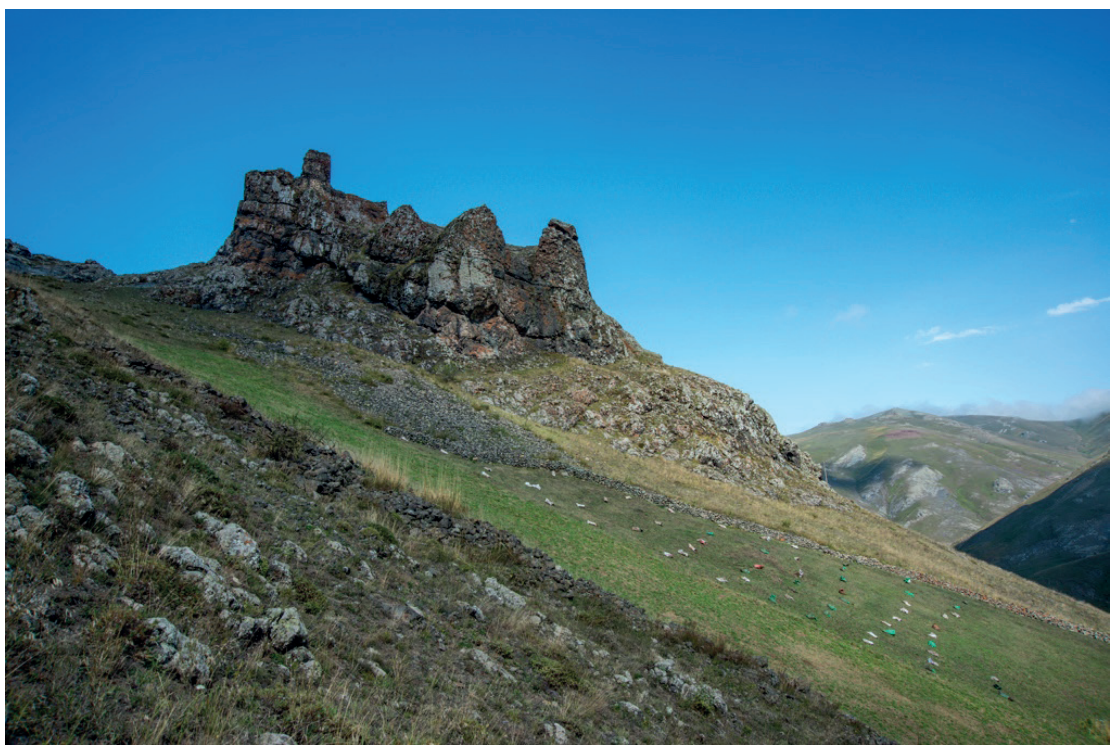

Resim 2. Kalecik Kalesi güneyden görünüm (Fotoğraf M. Güngör).
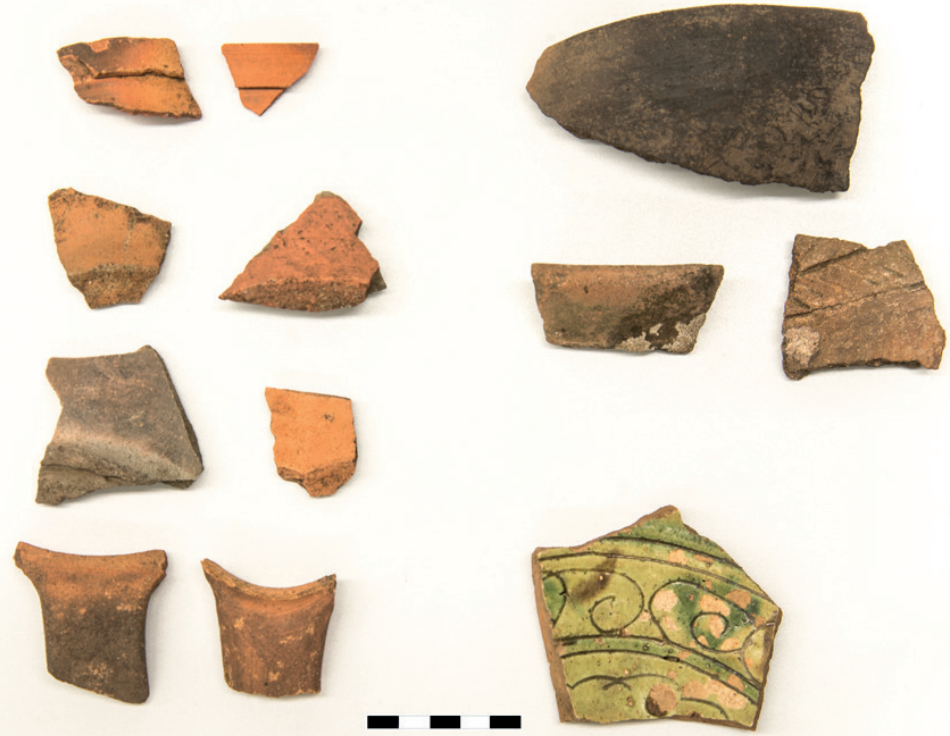

Resim 3. Kalecik Kalesi seçilmiş seramik buluntular (Fotoğraf M. Güngör). 


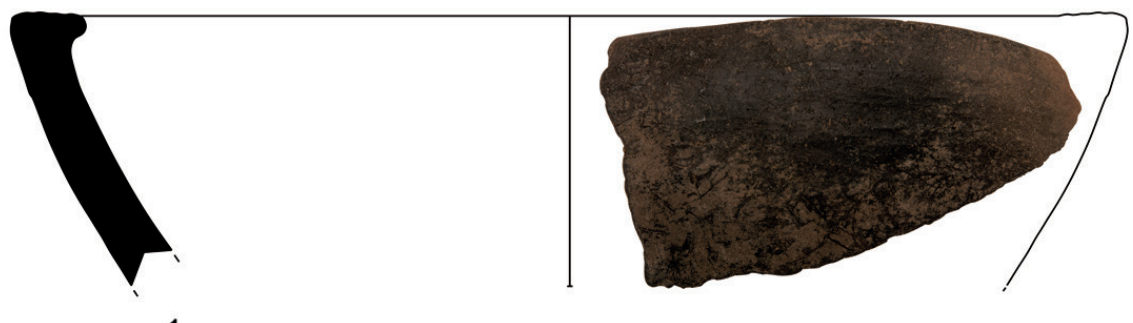

1

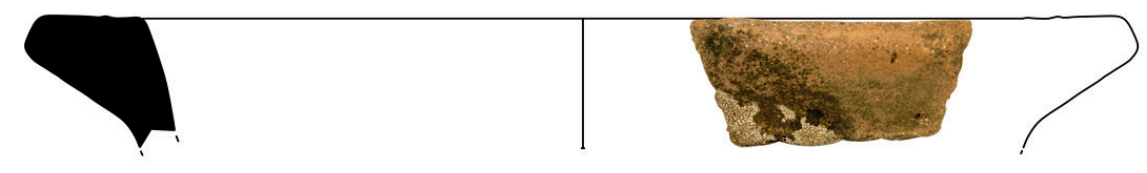

2

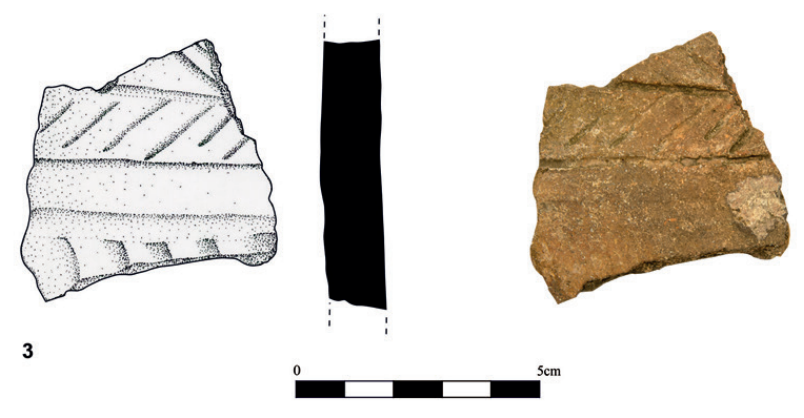

Resim 4. Kalecik Kalesi seçilmiş Erken Demir Çağı seramik buluntuları (Çizim D. Turan ve B. Gülkan; Fotoğraf M. Güngör). 


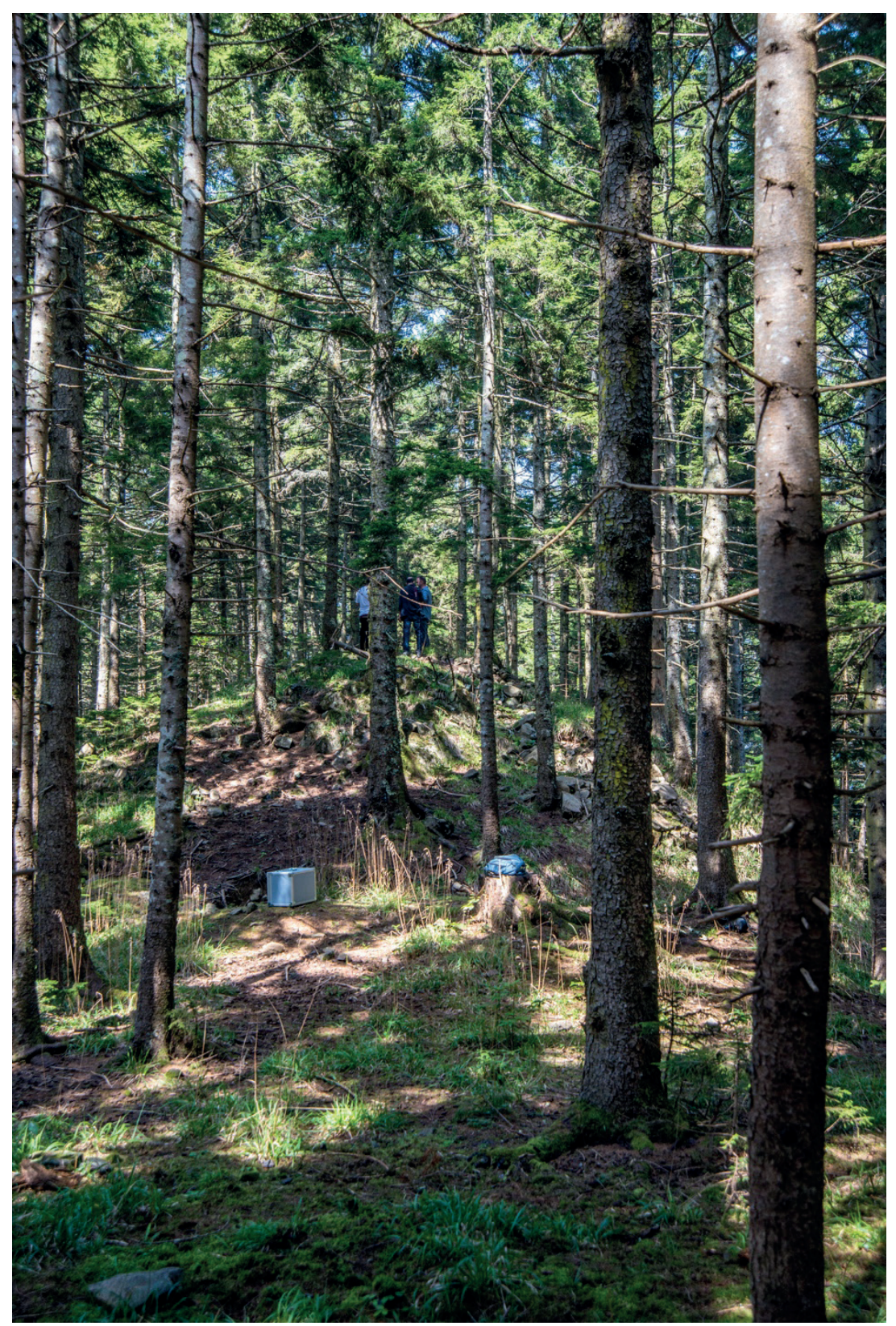

Resim 5. Konakdüzü Mevkii - Maçka/Trabzon (Fotoğraf M. Güngör). 


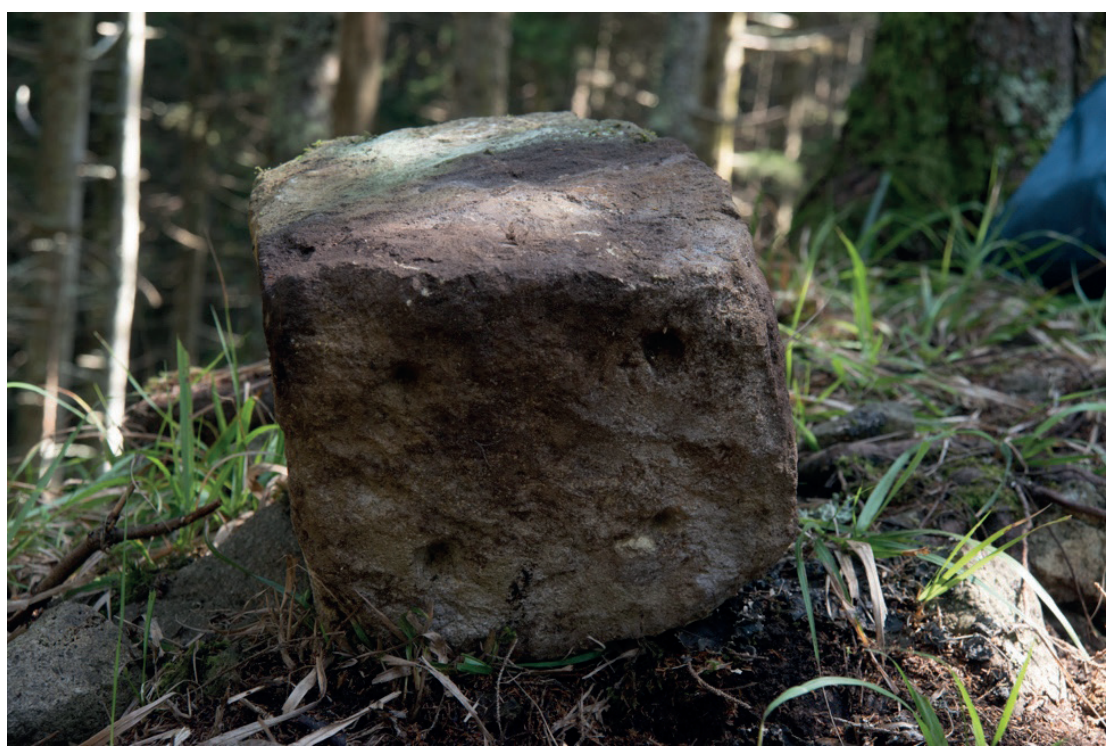

Resim 6. Konakdüzü Mevkii işlenmiş taş - Maçka/Trabzon (Fotoğraf M. Güngör).

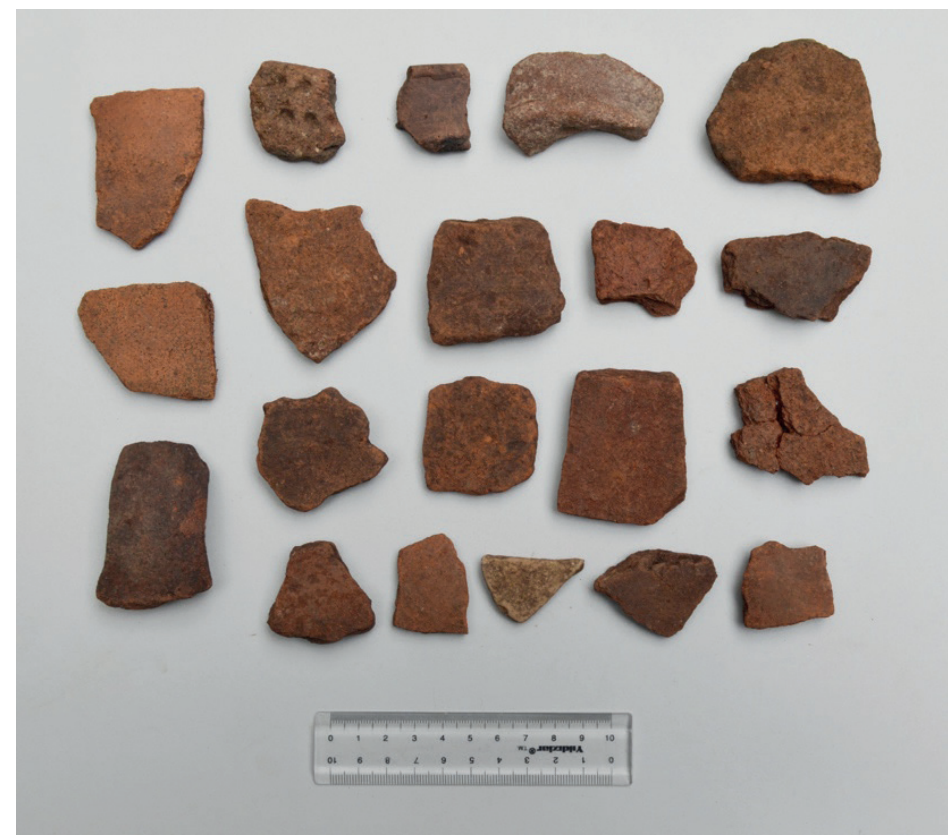

Resim 7. Konakdüzü Mevkii seçilmiş seramik buluntular (Fotoğraf Dr. S. Demirel). 

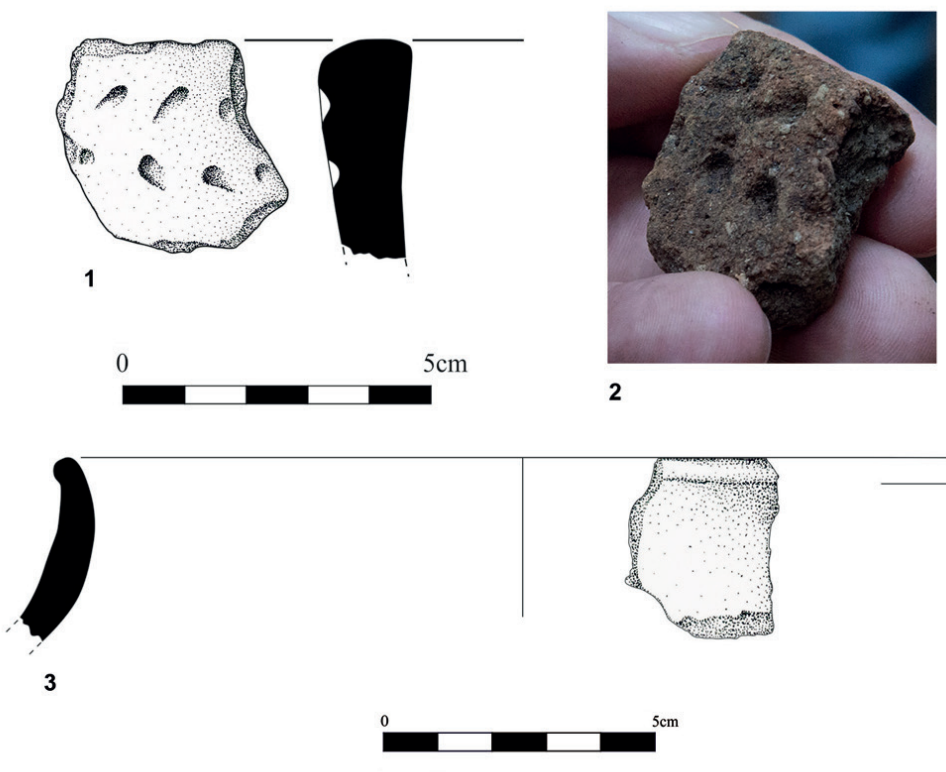

Resim 8. Konakdüzü Mevkii seramik parçaları (Çizim B. Gülkan; Fotoğraf M. Güngör).

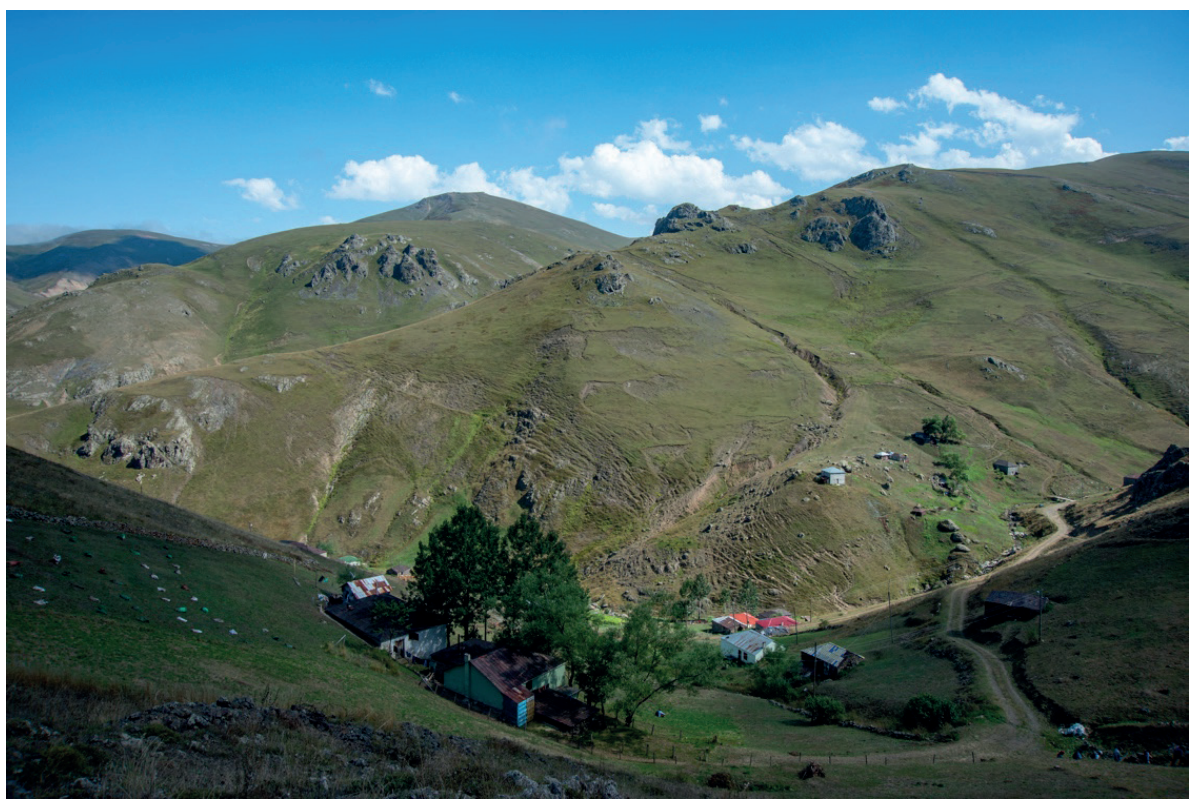

Resim 9. Kalecik Mezrası ve çevresi güneyden görünümü (Fotoğraf M. Güngör). 
